\title{
Treatment Regimen \#5
}

National Cancer Institute

\section{Source}

National Cancer Institute. Treatment Regimen \#5. NCI Thesaurus. Code C159878.

The fifth treatment regimen. 